\title{
Root electrical capacitance as an indicator of wheat growth and yield in a free-air carbon dioxide enrichment (FACE) experiment
}

Imre Cseresnyés ( $\square$ cseresnyes.imre@atk.hu )

Centre for Agricultural Research: Agrartudomanyi Kutatokozpont https://orcid.org/0000-0002-41989770

\section{Klára Pokovai}

Centre for Agricultural Research

\section{Zoltán Barcza}

Eötvös Loránd University

\section{Tibor A. Marton}

Centre for Agricultural Research

Nándor Fodor

Centre for Agricultural Research

\section{Research Article}

Keywords: aboveground biomass, climate change, in situ root monitoring, leaf area index, root system size

Posted Date: January 24th, 2022

DOI: https://doi.org/10.21203/rs.3.rs-1231959/v1

License: @ (i) This work is licensed under a Creative Commons Attribution 4.0 International License. Read Full License

Version of Record: A version of this preprint was published at Plant and Soil on February 25th, 2022. See the published version at https://doi.org/10.1007/s11104-022-05336-1. 


\section{Abstract}

Background and aims This study was the first to test the efficiency of monitoring root electrical capacitance $\left(\mathrm{C}_{\mathrm{R}}{ }^{*}\right)$ non-destructively in the field to evaluate crop development under different environmental conditions.

Methods A free-air $\mathrm{CO}_{2}$ enrichment (FACE) experiment was performed with two winter wheat cultivars, two levels (low and high) of nitrogen supply and two (ambient and elevated) of $\left[\mathrm{CO}_{2}\right]$ in three replicate plots over two years. The validity of $\mathrm{C}_{\mathrm{R}}{ }^{*}$ as a proxy for root uptake activity was confirmed by tracking the ceptometer-based leaf area index (LAl).

Results Repeated $\mathrm{C}_{\mathrm{R}}{ }^{*}$ measurements clearly demonstrated the seasonal dynamics in root development, with a peak at flowering, and the delayed growth in the second year caused by the unfavourable meteorological conditions. From the vegetative to flowering stages, $C_{R}{ }^{*}$ was strongly correlated with $\mathrm{LAl}$ $\left(R^{2}: 0.897-0.962\right)$. The positive effect of higher $\mathrm{N}$ supply and elevated $\left[\mathrm{CO}_{2}\right]$ on crop growth was clearly indicated by the higher $C_{R}{ }^{*}$ values, associated with increased LAl, shoot dry mass (SDM) at flowering and grain yield (GY). The maximum $C_{R}{ }^{*}$ was closely related to $G Y\left(R^{2}: 0.805\right.$ and 0.867$)$ when the data were pooled across the $\mathrm{N}$ and $\mathrm{CO}_{2}$ treatments and the years. Unlike $\mathrm{C}_{\mathrm{R}}{ }^{*}$ and $\mathrm{GY}, \mathrm{SDM}$ and LAI were significantly lower in the second year, presumably due to the enhanced root/shoot ratio induced by a severe spring drought.

Conclusions The present results convincingly demonstrated the potential of the in situ root capacitance method to assess root responses dynamically, and to predict crop GY.

\section{Introduction}

A vigorous, adaptive root system is critical for improved water and nutrient uptake, which in turn increases crop grain yield (GY), especially under stress conditions (Fang et al. 2017). Therefore, the measurement of root-related traits is just as important in agriculture as those of the shoot (Fageria 2013). As it is practically impossible to extract an intact root system from the field soil, non-destructive techniques need to be applied for root characterization, despite their inherent limitations (Ehosioke et al. 2020; Cabal et al. 2021).

The electrical capacitance method is considered a promising in situ phenotyping tool in plant breeding because it allows numerous plants to be measured repeatedly during the growing season, with the subsequent harvest of seeds for further reproduction (Chloupek et al. 2010; Středa et al. 2020). Unlike some other methods (root core, rhizotron), the capacitance technique provides information on individual plants due to the electrical separation of adjacent plants (Ellis et al. 2013). The electrical capacitance of the root-soil system $\left(C_{R}\right)$, measured between a ground and a plant electrode with alternating current (AC), was found to correlate with the root system size (RSS), including both root mass and length (Chloupek et al 2010; Carlson and Smart 2016). The first model by Dalton (1995) assumed that roots are leaky 
cylindrical capacitors with membrane dielectrics storing electric charges. The $C_{R}$ measured is related to the polarized membrane surface area. Various experiments verified that the root system was electrically connected along most of its length, but the contribution of distal fine roots to $C_{R}$ was uncertain (OzierLafontaine and Bajazet 2005; Ellis et al. 2013). Mary et al. (2018) found that AC reached the majority of the grapevine root system, penetrating to a depth of 30-40 cm into the soil. Conversely, others questioned Dalton's model and the efficacy of the $C_{R}$ method, observing localized current leakage in the proximal root part (Urban et al. 2011; Peruzzo et al. 2020). Dietrich et al. (2012) proposed a revised model, showing that $C_{R}$ was dominated by the stem between the plant electrode and the substrate surface, and was related to the stem cross-sectional area $\left(C_{R}-R S S\right.$ correlations were attributed merely to root-shoot allometry). Nevertheless, Cseresnyés et al. (2020b) experimentally demonstrated a strong dependence of $\mathrm{C}_{\mathrm{R}}$ on the mass of root branches in the soil, though the stem-base capacitance was considerable as well. Recent work revealed the potential of $C_{R}$ to directly quantify root traits in dry soil (which is more electrically resistive than the roots) rather than under wet conditions, i.e. at field capacity (Gu et al. 2021), a result which is relevant mainly for field studies. It is commonly agreed that, as root current pathways are affected by root water content, tissue density and suberization, the $C_{R}$ values represent not only the geometrical size but also the functional activity of the root system (Dalton 1995; Ellis et al. 2013; Peruzzo et al. 2020).

Besides numerous pot studies (summarized by Ehosioke et al. 2020), the $C_{R}$ method was efficiently used for evaluating RSS in field-grown wheat (Středa et al. 2012; Heřmanská et al. 2015; Cseresnyés et al. 2021), barley (Chloupek et al. 2006, 2010; Svačina et al. 2014), canola (Wu and Ma 2016), maize and soybean (Cseresnyés et al. 2018). Owing to the sensitivity of $C_{R}$ to external factors, capacitance data can only be compared when the same species is grown in the same substrate and measured with the same electrode type and placement (Chloupek et al. 2006; Středa et al. 2012). Variation in soil water content (SWC) has a marked effect on $C_{R}$ due to changes in soil-ground electrode contact (Ellis et al. 2013) and in the root to soil conductance ratio (Gu et al. 2021). A close positive relationship between $C_{R}$ and the SWC of the root zone was previously shown for several species (Cseresnyés et al. 2018, 2020a). Using a species-specific exponential function, a saturation capacitance, $C_{R}{ }^{*}$ (which can be detected in watersaturated soil) was calculated from the measured $C_{R}$ and the corresponding SWC. This transformation allowed a comparison of the field data recorded under different SWC values at different dates (for a detailed description, see Cseresnyés et al. 2018). In this manner, the ontogenic pattern of $C_{R}{ }^{*}$ was revealed, as a proxy for root uptake activity for field-grown maize and soybean with a peak at flowering, in accordance with previous findings obtained using conventional root methods (Fageria 2013).

Nevertheless, to date there has been no field research aimed at using the capacitance method to monitor root dynamics in situ in crops grown under different cultivation and environmental conditions. Due to global climate change, many experiments have aimed to study the plant response to increased atmospheric carbon dioxide concentration ( $\left[\mathrm{CO}_{2}\right]$ ) over the past few decades, focusing on the major food crops (Kirkham et al. 2011; Wang et al. 2013; Broberg et al. 2019). Root dynamics and production are 
reported to have key roles in plant adaptation to rising $\left[\mathrm{CO}_{2}\right]$ (Benlloch-Gonzalez et al. 2014). Several studies have shown that elevated $\left[\mathrm{CO}_{2}\right]$ resulted in an increased root growth rate in cereals, including wheat (Wechsung et al. 1999; Uddin et al. 2018). Nowadays, free-air $\mathrm{CO}_{2}$ enrichment (FACE) experiments have been prioritized worldwide for evaluating crop responses to the future climate (Kirkham 2011), as they provide more realistic field conditions compared to enclosed systems such as open-top chambers (Broberg et al. 2019). As the small plot sizes and the huge investment and maintenance costs arising in FACE systems necessitate minimizing soil disturbance and destructive plant sampling during the growing season, the use of high-throughput, in situ root methods is definitely preferable.

Therefore, a FACE experiment ("MartonFACE") was chosen to test the efficiency of monitoring $\mathrm{C}_{\mathrm{R}}{ }^{*}$ to evaluate the response of wheat to an altered environment, such as different $\mathrm{N}$ fertilization rates and elevated $\left[\mathrm{CO}_{2}\right]$, non-intrusively. The specific aims were: $(i)$ to determine the temporal pattern of $\mathrm{C}_{\mathrm{R}}{ }^{*}$ in relation to plant phenology stages in two winter wheat cultivars from different maturity groups over two growing seasons; (ii) to investigate the effect of $\mathrm{N}$ level, elevated $\left[\mathrm{CO}_{2}\right]$ and their interaction on $\mathrm{C}_{\mathrm{R}}{ }^{*}$ during the crop growth period; and (iii) to study the relationship between $\mathrm{C}_{\mathrm{R}}{ }^{*}$ and leaf area index (LAI) detected non-destructively on several occasions up till wheat flowering. Considering that $C_{R}{ }^{*}$ is likely influenced by shoot traits, and LAl is a determinant of root activity (water use) via whole-plant transpiration, $\mathrm{C}_{\mathrm{R}}{ }^{*}-\mathrm{LAl}$ regressions served to indirectly validate the capacitance method. Furthermore, correlations were determined between: (iv) the maximum $\mathrm{C}_{\mathrm{R}}{ }^{*}$ measured at anthesis and the total aboveground biomass (TAB) and grain mass (GM) per plant measured at maturity for both cultivars at the plant scale; and ( $v$ ) the maximum $\mathrm{C}_{\mathrm{R}}{ }^{*}$ and shoot dry mass (SDM; at the end of flowering) and GY (at maturity) across treatments and years at stand scale. Overall, the aim was to provide a useful tool to assess plant performance and yield in the field for, among other things, the selection of crop genotypes with improved adaptability to changing conditions.

\section{Materials And Methods \\ Site description}

The field trial was carried out in the nursery of the Centre for Agricultural Research, Martonvásár, Central

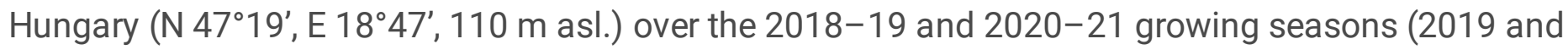
2021 hereafter). The soil is classified by FAO-WRB (IUSS Working Group 2015) as a Haplic Chernozem (34\% sand, $42 \%$ silt and $24 \%$ clay in the $0-25 \mathrm{~cm}$ layer), with a $\mathrm{pH}_{\mathrm{H} 2 \mathrm{O}}$ of $7.59,1.84 \% \mathrm{CaCO}_{3}, 3.39 \%$ humus, $1799 / 374 / 429 \mathrm{mg} \mathrm{kg}^{-1}$ total $\mathrm{N} / \mathrm{P} / \mathrm{K}$, and 0.322 and $0.476 \mathrm{~cm}^{3} \mathrm{~cm}^{-3}$ water content at field capacity and saturation point, respectively.

The climate is continental with a mean (1988-2017; recorded by an on-site weather station) annual temperature of $10.9^{\circ} \mathrm{C}$ (January: $-1.2^{\circ} \mathrm{C}$, June: $21.2^{\circ} \mathrm{C}$ ) and total rainfall of $552 \mathrm{~mm}$ with $193 \mathrm{~mm}$ falling during the main winter wheat growing season (March-June; Fig. 1). 2019 was $1-1.5^{\circ} \mathrm{C}$ warmer and $55 \%$ drier from January to April than the long-term mean. In contrast, May was very wet with $139 \mathrm{~mm}(239 \%)$ 
precipitation, followed by a relatively normal June. In 2021, April and May were very cold $\left(3^{\circ} \mathrm{C}\right.$ below the average), and March and June were extremely dry with only $3 \mathrm{~mm}(10 \%)$ and $4 \mathrm{~mm}(6 \%)$ total rainfall, respectively.

\section{Crop cultivation and FACE system}

A factorial experiment was set up in three replicates with (1) two winter wheat (Triticum aestivum L.) cultivars: the early maturing Mv Nemere and the medium-early Mv Dandár, (2) two levels of N supply: low (80 kg ha ${ }^{-1}$ ) and high (160 kg ha $\left.{ }^{-1}\right)$, and (3) two levels of $\left[\mathrm{CO}_{2}\right]$ : ambient and elevated to $600 \mathrm{ppm}$. The soil was ploughed and fertilized with ammonium nitrate. Wheat was sown in mid-October 2018 and 2020 at a density of 500 seedlings $\mathrm{m}^{-2}$ with a row spacing of $12.5 \mathrm{~cm}$. The crop stand was sprayed with a pesticide combination at the 3-leaf stage in April.

The FACE system was engineered by the Institute for Biometeorology, Italian National Research Council, Florence (for details, see Miglietta et al. 2013). The facility consisted of three 18-m diameter octagonal rings ( $\left.250 \mathrm{~m}^{2}\right)$ of horizontal tubes releasing pure $\mathrm{CO}_{2}$ on the upwind side to a targeted $\left[\mathrm{CO}_{2}\right]$ of 600 ppm. A GMP343 type sensor (Vaisala Co. Ltd., Helsinki, Finland) was installed centrally in each ring to monitor $\left[\mathrm{CO}_{2}\right]$ and control the venting. The plots were fumigated from crop emergence to the fully ripe stage during the daylight hours, except when air temperature fell below $0^{\circ} \mathrm{C}$. The tubes were kept at a height of 0.1-0.2 $\mathrm{m}$ above the wheat canopy. The average $\left[\mathrm{CO}_{2}\right]$ in the FACE rings during the treatment period was 597 and 587 ppm in 2019 and 2021, respectively, and was within 600 ppm \pm 10\% for 76.2\% and $69.5 \%$ and within 600 ppm $\pm 20 \%$ for $94.2 \%$ and $90.8 \%$ of the operational time in the given years. Three further rings without $\mathrm{CO}_{2}$ enrichment were established as control (ambient) plots.

\section{Monitoring of root electrical capacitance and leaf area index}

$\mathrm{C}_{\mathrm{R}}$ was measured eight times between the 2-node stage (late March) and the over-ripe stage of wheat (early July) to monitor the seasonal root dynamics. The phenology stages were documented using the BBCH scale (Meier 2001). On each occasion, twelve plants were randomly selected in the centre of each plot (36 plants per treatment, 288 plants in total). SWC was measured at a depth of 0-12 cm in the root zone of each sample plant with a calibrated CS620 portable TDR meter (Campbell Sci. Ltd., Loughborough, UK), inserting the sensor vertically in the interrow, $6 \mathrm{~cm}$ away from the plant.

Thereafter, $\mathrm{C}_{\mathrm{R}}$ was measured for each plant in a parallel circuit at $1 \mathrm{kHz}, 1 \mathrm{~V}$ AC with a U1733C handheld LCR instrument (Agilent Co. Ltd., Penang, Malaysia). A stainless steel rod, $15 \mathrm{~cm}$ in length and $6 \mathrm{~mm}$ in diameter, was used as a ground electrode, pushed vertically into the soil to a depth of $12 \mathrm{~cm}, 6 \mathrm{~cm}$ distance from the plant (in the place of the TDR probe). The plant electrode was clamped to all basal parts of the plant $15 \mathrm{~mm}$ above the soil (Svačina et al. 2014), after smearing them with conductivity gel to ensure good electric contact. The measured volumetric SWC values were divided by the saturation water content to obtain the relative water saturation $\left(\theta_{\text {rel }}\right)$. The saturation capacitance was calculated for 
each of the $288 \theta_{\text {rel }}-C_{R}$ data pairs as $C_{R}{ }^{*}=C_{R} \times 5.807 e^{-1.115 \theta r e l}$ to eliminate the SWC effect. The procedure for calculating the exponential function was previously reported in detail by Cseresnyés et al. (2018).

LAI was measured non-destructively in each plot five times in each growing season, on the same dates as the $\mathrm{C}_{\mathrm{R}}$ measurements (or 1-2 days later due for weather reasons). The monitoring terminated at the wheat flowering stage (mid-May), when LAl peaked but the reading was not yet affected by leaf senescence (Pokovai and Fodor 2019). LAl was detected during clear midday hours (from 10 a.m. to 2 p.m.) using an LP-80 handheld ceptometer (Meter Group Inc., Pullmann, WA, USA). Each LAI value, calculated as a mean of 22 readings, represented a $\sim 0.6 \mathrm{~m}^{2}$ area under the canopy. The $80 \mathrm{~cm}$ long probe was placed parallel and perpendicular to the crop rows, and was read twice in each position.

\section{Plant sampling and harvest}

In 2019 destructive plant sampling had to be postponed from anthesis to the end of flowering owing to bad weather conditions, so sampling was also carried out in this stage in 2021 to ensure comparability. A $0.5 \mathrm{~m}$ long row was manually cut just above the soil surface in each plot. After drying the samples at $70^{\circ} \mathrm{C}$, SDM was determined $( \pm 0.01 \mathrm{~g})$ and expressed as $\mathrm{t} \mathrm{ha}^{-1}$ values.

Plants from the central $2 \mathrm{~m} \times 6 \mathrm{~m}$ area of each plot were harvested and threshed at grain maturity (midJuly 2019 and 2021) using a plot combine. GY was determined in $\mathrm{t} \mathrm{ha}^{-1}$ on a dry weight basis.

Considering that only one GY value was obtained per plot (though they represented a relatively large area), a plant scale investigation was also carried out to confirm the relationship of $C_{R}{ }^{*}$ to TAB and GM. On the day in 2019 when $C_{R}{ }^{*}$ measurements were taken at the flowering stage (day of year, DOY 140), the 36 sample plants in the " $\mathrm{NL}(-)$ " and " $\mathrm{DL}(-)$ " treatments were individually tagged at the stem base. These plants were cut separately at maturity, after which TAB was weighed $( \pm 0.001 \mathrm{~g})$ after drying at $70^{\circ} \mathrm{C}$. The spikes were hand threshed to record GM.

\section{Statistical analysis}

The data were analysed in R programming language (R Core Team 2021). Two-way ANOVA was used to examine the effect of $\mathrm{N}, \mathrm{CO}_{2}$ and $\mathrm{N} \times \mathrm{CO}_{2}$ on $\mathrm{C}_{\mathrm{R}}{ }^{*}$, LAl, SDM and $\mathrm{GY}$ within each year. Multivariate ANOVA was performed to evaluate the effect of year, $\mathrm{N}, \mathrm{CO}_{2}$ and their interactions on the maximum $\mathrm{C}_{\mathrm{R}}{ }^{*}$, maximum LAI, SDM and GY. The normality, and the equality of variances in the data groups were examined with the Shapiro-Wilk test and Levene test, respectively. Statistical significance was assessed at $p<0.05$ in each case.

Linear regression models were compiled: $(i)$ to evaluate the relationships between $C_{R}{ }^{*}$ and $L A l$ (across the $\mathrm{N}$ and $\mathrm{CO}_{2}$ treatments), and between the maximum $\mathrm{C}_{\mathrm{R}}{ }^{*}, \mathrm{SDM}$ and $\mathrm{GY}$ (across the $\mathrm{N}$ and $\mathrm{CO}_{2}$ treatments and years) at a stand scale; and (ii) to relate $C_{R}{ }^{*}$ to $T A B$ and $G M$ at a plant scale for the cultivars. The line slopes and $y$-intercepts were compared using ANOVA. The reason for applying the maximum $\mathrm{C}_{\mathrm{R}}{ }^{*}$ 
(measured at flowering) was that it previously proved to be the best predictor of yield (Chloupek et al. 2006).

\section{Results}

\section{Root electrical capacitance}

In 2019 the mean $C_{R}{ }^{*}$ increased sharply during vegetative growth until the flag-leaf stage (BBCH 37-39; DOY 113) and then moderately until flowering (BBCH 61-69; DOY 140), when it reached a maximum of 10.6-12.7 nF, finally decreasing during the maturity stages (Fig. 2). The higher $\mathrm{N}$ level caused a significant increase in $\mathrm{C}_{R}{ }^{*}$ from the flag-leaf stage to the milk stages (BBCH 73-75; DOY 154). At flowering this increase was 2-8\% for Mv Nemere and $4 \%$ for Mv Dandár (Table 1). The effect of elevated $\left[\mathrm{CO}_{2}\right]$ proved to be significant from the 3-node stage (BBCH 33; DOY 88) to the dough stages (BBCH 8387; DOY 169), enhancing $C_{R}{ }^{*}$ at flowering by $12-18 \%$ and $12-16 \%$ for Mv Nemere and Mv Dandár, respectively. A significant $\mathrm{N} \times \mathrm{CO}_{2}$ interaction was only found for Mv Nemere at DOY 113. 
Table 1

Two-way ANOVA results for the effect of nitrogen $(\mathrm{N}), \mathrm{CO}_{2}$ and $\mathrm{N} \times \mathrm{CO}_{2}$ on plant parameters for wheat cultivars Mv Nemere and Mv Dandár in two years. DOY Day of year, $\mathrm{C}_{\mathrm{R}}{ }^{*}$ - Saturation root electrical capacitance, LAl - Leaf area index, SDM - Shoot dry mass, GY - Grain yield. $\left.{ }^{*}\right) p<0.1,{ }^{*} p<0.05,{ }^{* \star} p<0.01$, ${ }^{\star \star \star} p<$ 0.001, NS not significant.

\begin{tabular}{|c|c|c|c|c|c|c|c|c|}
\hline \multirow[t]{2}{*}{ Year } & \multirow[t]{2}{*}{ Parameter } & \multirow[t]{2}{*}{ DOY } & \multicolumn{3}{|c|}{ Mv Nemere } & \multicolumn{3}{|c|}{ Mv Dandár } \\
\hline & & & $\mathbf{N}$ & $\mathrm{CO}_{2}$ & $\mathrm{~N} \times \mathrm{CO}_{2}$ & $\mathbf{N}$ & $\mathrm{CO}_{2}$ & $\mathrm{~N} \times \mathrm{CO}_{2}$ \\
\hline \multirow[t]{15}{*}{2019} & $\mathrm{C}_{\mathrm{R}}{ }^{*}$ & 88 & NS & $\star \star \star \star$ & NS & NS & $\star \star \star *$ & NS \\
\hline & & 99 & $\left({ }^{\star}\right)$ & $\star \star \star *$ & NS & NS & $\star \star \star \star$ & NS \\
\hline & & 113 & $\star \star$ & $\star \star \star *$ & * & $\star \star$ & $\star \star \star$ & NS \\
\hline & & 128 & * & $\star \star \star *$ & NS & * & $\star \star \star *$ & NS \\
\hline & & 140 & * & 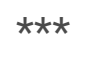 & NS & * & $\star \star \star *$ & NS \\
\hline & & 154 & $\star \star$ & 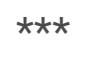 & NS & $\star \star$ & $\star \star \star \star ~$ & NS \\
\hline & & 169 & NS & ** & NS & NS & $\star \star \star *$ & $\left({ }^{\star}\right)$ \\
\hline & & 185 & NS & NS & NS & NS & * & NS \\
\hline & LAl & 88 & NS & 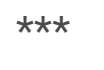 & NS & $\left({ }^{*}\right)$ & $\star \star \star *$ & NS \\
\hline & & 99 & NS & $(*)$ & $\left({ }^{*}\right)$ & NS & * & NS \\
\hline & & 114 & $\left({ }^{*}\right)$ & NS & NS & NS & NS & NS \\
\hline & & 128 & NS & NS & NS & NS & * & NS \\
\hline & & 144 & NS & NS & NS & NS & * & NS \\
\hline & SDM & & NS & $\star \star$ & * & NS & $\left({ }^{\star}\right)$ & * \\
\hline & GY & & NS & $\star \star \star$ & * & NS & $\star \star \star$ & NS \\
\hline \multirow[t]{8}{*}{2021} & $C_{R}^{*}$ & 89 & * & $\star \star \star *$ & NS & NS & * & NS \\
\hline & & 99 & * & $\star \star \star \star$ & NS & $\star \star \star$ & $\star \star \star *$ & * \\
\hline & & 113 & 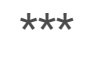 & $\star \star \star *$ & NS & $\star \star \star$ & $\star \star$ & NS \\
\hline & & 127 & $\star \star \star$ & $\star \star \star *$ & NS & $\star \star$ & NS & 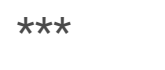 \\
\hline & & 145 & $\star \star \star$ & 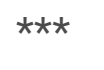 & NS & $\star \star \star$ & $\star \star \star *$ & $\star \star \star \star$ \\
\hline & & 159 & $\star \star \star *$ & $\star \star \star ~$ & NS & $\star \star \star \star$ & $\star \star \star *$ & $\star \star \star *$ \\
\hline & & 174 & 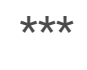 & 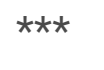 & NS & $\star \star$ & 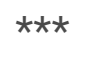 & * \\
\hline & & 189 & NS & $\left({ }^{\star}\right)$ & NS & NS & NS & NS \\
\hline
\end{tabular}




\begin{tabular}{|c|c|c|c|c|c|c|c|c|}
\hline \multirow[t]{2}{*}{ Year } & \multirow[t]{2}{*}{ Parameter } & \multirow[t]{2}{*}{ DOY } & \multicolumn{3}{|c|}{ Mv Nemere } & \multicolumn{3}{|c|}{ Mv Dandár } \\
\hline & & & $\mathbf{N}$ & $\mathrm{CO}_{2}$ & $\mathrm{~N} \times \mathrm{CO}_{2}$ & $\mathbf{N}$ & $\mathrm{CO}_{2}$ & $\mathrm{~N} \times \mathrm{CO}_{2}$ \\
\hline \multirow{5}{*}{\multicolumn{2}{|c|}{ LAI }} & 89 & NS & $\star \star \star *$ & * & $\star \star \star *$ & $\star \star \star *$ & $\star *$ \\
\hline & & 99 & * & $\star \star \star$ & $(*)$ & $\star \star \star$ & $\star \star$ & * \\
\hline & & 113 & $\star \star \star *$ & $\star \star \star$ & NS & $\star \star \star$ & * & * \\
\hline & & 126 & $\star \star$ & $(*)$ & NS & $(*)$ & NS & * \\
\hline & & 146 & NS & NS & NS & $\star *$ & * & $\left({ }^{*}\right)$ \\
\hline & SDM & & NS & ** & NS & $(*)$ & * & NS \\
\hline & GY & & NS & $\star \star$ & NS & * & NS & * \\
\hline
\end{tabular}

In 2021 a severe drought in March and a prolonged cold period led to a considerable delay in wheat development and postponed anthesis by $8-10$ days. This was also indicated by the capacitance data: initially, $C_{R}{ }^{*}$ showed a slower increase during vegetative growth, but thereafter it reached a maximum of 10.5-13.5 nF for Mv Nemere and 10.8-13.0 nF for Mv Dandár at flowering (DOY 145). Thus, there was no significant year effect on the maximum $\mathrm{C}_{\mathrm{R}}{ }^{*}$ for the cultivars (Table 2 ). The higher $\mathrm{N}$ rate positively influenced the root activity from the 3-node stage (DOY 99) to the late milk stage (BBCH 77; DOY 174). In the case of Mv Nemere, a 9-10\% increase in $C_{R}{ }^{*}$ was observed at flowering. For Mv Dandár, however, the maximum $\mathrm{C}_{\mathrm{R}}{ }^{*}$ remained unchanged $(0 \%)$ or increased by $20 \%$ under ambient and elevated $\left[\mathrm{CO}_{2}\right]$, respectively. Elevated $\left[\mathrm{CO}_{2}\right]$ significantly influenced $\mathrm{C}_{\mathrm{R}}{ }^{*}$ during most of the growth cycle for $\mathrm{Mv}$ Nemere with a 17-18\% increase at flowering. The effect was weaker for Mv Dandár with no change ( $0 \%)$ and a $19 \%$ increase in $C_{R}{ }^{*}$ in the low and high $N$ treatments, respectively. This cultivar showed a significant $N \times$ $\mathrm{CO}_{2}$ effect at several measurement dates. 
Table 2

Multivariate ANOVA results for the effect of year $(\mathrm{Y})$, nitrogen $(\mathrm{N})$ and $\mathrm{CO}_{2}$ and their interactions on the maximum saturation root electrical capacitance $\left(\mathrm{C}_{\mathrm{R}}{ }^{*}\right)$, maximum leaf area index (LAl), shoot dry mass (SDM) and grain yield (GY) for wheat cultivars Mv Nemere and Mv Dandár. $\left({ }^{*}\right) p$ $<0.1, * p<0.05, * \star p<0.01, * \star * p<0.001$, NS not significant.

\begin{tabular}{|c|c|c|c|c|c|c|c|c|}
\hline Cultivar & Parameter & $Y$ & $\mathbf{N}$ & $\mathrm{CO}_{2}$ & $\mathrm{Y} \times \mathrm{N}$ & $\mathrm{Y} \times \mathrm{CO}_{2}$ & $\mathrm{~N} \times \mathrm{CO}_{2}$ & $\mathrm{Y} \times \mathrm{N} \times \mathrm{CO}_{2}$ \\
\hline \multirow[t]{4}{*}{ Mv Nemere } & $\max . \mathrm{C}_{\mathrm{R}}{ }^{*}$ & NS & $\star \star \star \star ~$ & $\star \star \star ~$ & NS & NS & NS & NS \\
\hline & max. LAI & $\star \star \star$ & NS & * & NS & NS & NS & NS \\
\hline & SDM & * & NS & 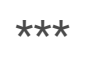 & NS & NS & NS & NS \\
\hline & GY & $(*)$ & NS & 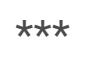 & NS & NS & NS & NS \\
\hline \multirow[t]{4}{*}{ Mv Dandár } & $\max . C_{R}{ }^{*}$ & NS & 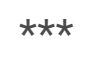 & $\star \star \star ~$ & * & * & $\star \star \star *$ & $\star \star$ \\
\hline & max. LAI & $\star \star \star *$ & * & $\star \star$ & NS & NS & NS & NS \\
\hline & SDM & $\star \star \star \star ~$ & NS & $\star *$ & NS & NS & NS & * \\
\hline & GY & NS & * & $\star \star$ & * & * & NS & NS \\
\hline
\end{tabular}

\section{Leaf area index}

In 2019 LAl steadily increased over time until wheat flowering, up to $5.6-7.7 \mathrm{~m}^{2} \mathrm{~m}^{-2}$ for Mv Nemere and 4.7-7.3 $\mathrm{m}^{2} \mathrm{~m}^{-2}$ for Mv Dandár (Fig. 3). The higher $\mathrm{N}$ supply increased the maximum LAl by $11-18 \%$ and $16-22 \%$ for these cultivars. However, differences in LAl between the $\mathrm{N}$ treatments were only marginally significant $(p<0.1)$ in some cases, likely partly due to the small number of replicates $(n=3$; Table 1$)$. The elevated $\left[\mathrm{CO}_{2}\right]$ significantly increased LAl during the vegetative growth (DOY 88 and 99 ) for both cultivars, and also at the heading (DOY 128) and the flowering stages for Mv Dandár. The maximum LAI proved to be $18-25 \%$ higher for $\mathrm{Mv}$ Nemere and $27-33 \%$ higher for Mv Dandár under $\left[\mathrm{CO}_{2}\right]$ enrichment.

Very small LAI was measured early in the season in 2021 due to the slow shoot growth rate. Thereafter, this was partly compensated for by more vigorous development up to an LAl of $3.0-4.3 \mathrm{~m}^{2} \mathrm{~m}^{-2}$ for Mv Nemere and 3.1-6.2 $\mathrm{m}^{2} \mathrm{~m}^{-2}$ for Mv Dandár. The maximum LAI was significantly lower in 2021 than in 2019, by $44-49 \%$ and $16-46 \%$ for Mv Nemere and Mv Dandár, respectively (Table 2). Enhanced N supply resulted in a significant increase in LAI in most phenophases, with the relative effect of $2 \%$ (Mv Nemere) and $24 \%$ (Mv Dandár) under ambient, and $23 \%$ and $79 \%$ under elevated $\left[\mathrm{CO}_{2}\right]$ at flowering. The positive impact of $\mathrm{CO}_{2}$ treatment on LAl proved to be significant in most cases. The effect on the maximum LAI was 18\% (Mv Nemere) and 9\% (Mv Dandár) in the low $\mathrm{N}$, and $42 \%$ and $60 \%$ in the high $\mathrm{N}$ treatments. $\mathrm{A}$ significant $\mathrm{N} \times \mathrm{CO}_{2}$ effect was observed chiefly for Mv Dandár.

A strongly significant positive linear relationship was found between $C_{R}{ }^{*}$ and the corresponding LAl for each cultivar and year $\left(R^{2}: 0.897-0.962 ; p<0.001 ; n=20\right)$ when the data were pooled across the $N$ and 
$\mathrm{CO}_{2}$ treatments (Fig. 4). The regression parameters were statistically equal for the cultivars in 2019, whereas Mv Nemere had a steeper line $(p<0.001)$ in 2021. The slope of the regressions differed significantly between years for Mv Nemere $(p<0.001)$ and the $y$-intercept for both cultivars $(p<0.05)$.

\section{Shoot dry mass and grain yield}

Wheat SDM ranged from 14.9 to $23.5 \mathrm{t} \mathrm{ha}^{-1}$ for Mv Nemere and from 14.4 to $20.6 \mathrm{t} \mathrm{ha}^{-1}$ for Mv Dandár in 2019, and from 11.7 to $17.3 \mathrm{t} \mathrm{ha}^{-1}$ and 8.2 to $14.0 \mathrm{t} \mathrm{ha}^{-1}$ in 2021 (Fig. 5). SDM was significantly lower in 2021 than in 2019 (Table 2), by 5-26\% and 18-56\% for Mv Nemere and Mv Dandár, respectively. There was no significant $\mathrm{N}$ effect on SDM, except for a marginal $(p<0.1)$ increase for Mv Dandár in 2021 (Table 1). Elevated $\left[\mathrm{CO}_{2}\right]$ led to a significant increase in SDM (but only marginally for Mv Dandár in 2019): the relative change ranged from $-1-58 \%$, with higher responses under low $\mathrm{N}$ conditions. A significant $\mathrm{N} \times$ $\mathrm{CO}_{2}$ effect was shown for the cultivars in 2019.

A GY of 4.75-7.47 tha ${ }^{-1}$ and 4.81-6.80 $\mathrm{tha}^{-1}$ was produced by Mv Nemere and Mv Dandár, respectively, in 2019, and 4.22-6.98 tha $\mathrm{th}^{-1}$ and 5.24-7.66 $\mathrm{t} \mathrm{ha}^{-1}$ in 2021 (Fig. 5). GY for Mv Nemere was marginally significantly $(p=0.05)$ lower in 2021 than in 2019; the difference was insignificant for Mv Dandár. The $N$ effect was significant only for Mv Dandár in 2021, when $2 \%$ and $46 \%$ yield increases were observed under ambient and elevated $\left[\mathrm{CO}_{2}\right]$, respectively. The $\left[\mathrm{CO}_{2}\right]$ enrichment significantly increased $\mathrm{GY}$ for the two cultivars in 2019, and for Mv Nemere in 2021, with more pronounced differences in the low N (41-57\%) than in the high $\mathrm{N}$ treatment (12-37\%). As for Mv Dandár in 2021, GY was reduced by $9 \%$ but enhanced by $30 \%$ in the $\mathrm{CO}_{2}$ treatments under low and high $\mathrm{N}$ supply, respectively. Significant $\mathrm{N} \times \mathrm{CO}_{2}$ effects were found for Mv Nemere in 2019 and for Mv Dandár in 2021.

The relationship between the maximum $C_{R}{ }^{*}$ and SDM proved to be insignificant (Mv Nemere: $R^{2}: 0.423$; Mv Dandár: $\mathrm{R}^{2}:$ 0.187), when the data were pooled across $\mathrm{N}$ and $\mathrm{CO}_{2}$ treatments and years (Fig. 6). In contrast, the linear correlations between the maximum $\mathrm{C}_{\mathrm{R}}{ }^{*}$ and $\mathrm{GY}$ were significant both for $\mathrm{Mv}$ Nemere $\left(R^{2}: 0.805 ; p<0.01\right)$ and Mv Dandár $\left(R^{2}: 0.867 ; p<0.01\right)$, with equal regression parameters for the cultivars.

\section{Plant-scale correlations}

Considering the individual wheat plants, $C_{R}{ }^{*}$ measured at anthesis was significantly correlated with TAB $\left(R^{2}: 0.715\right.$ and $\left.0.727 ; p<0.001\right)$ and $G Y\left(R^{2}: 0.648\right.$ and $\left.0.661 ; p<0.001\right)$ for each cultivar (Fig. 7). No significant differences in line parameters were found between the cultivars for the $C_{R}{ }^{*}-T A B$ and $C_{R}{ }^{*}-G Y$ regressions.

\section{Discussion}

\section{Seasonal patterns}


The monitoring of $\mathrm{C}_{\mathrm{R}}{ }^{*}$ demonstrated marked seasonal dynamics in wheat root development with a peak at the flowering stage, as well as delayed early vegetative growth in 2021 , linked to substantially smaller LAI. Similar temporal variations in wheat root biomass, root length and water use were previously shown in the field using the minirhizotron (Asseng et al. 1998; Uddin et al. 2018) or soil core methods (Xue et al. 2003; Jha et al. 2017). The root pattern is related to ontogenic changes in LAl and whole-plant transpiration (Yang et al. 2018). In cereals this trend is caused by strong resource allocation to the roots until flowering and subsequent nutrient translocation for reproductive growth (Fageria 2013). The sudden decrease in $C_{R}{ }^{*}$ after the flowering stages can be explained by reduced relative permittivity in aging roots owing to tissue maturation, lignification and senescence (Dalton 1995; Ellis et al. 2013).

The shorter growth period (6-8 days earlier flowering) of Mv Nemere compared to Mv Dandár was indicated by a moderate increase in $\mathrm{C}_{\mathrm{R}}{ }^{*}$ between DOY 128 and 140 in 2019 . Elevated $\left[\mathrm{CO}_{2}\right]$ hastened the flowering of the cultivars by 3-4 days in 2019 but not in 2021. This is in line with reports that $\mathrm{CO}_{2}$ treatment generally had a small and inconsistent effect on wheat phenology (Kirkham 2011; Wang et al. 2013).

\section{Responses to higher $\mathrm{N}$ level and elevated $\left[\mathrm{CO}_{2}\right]$}

In the present study, the positive effect of elevated $\mathrm{N}$ and $\left[\mathrm{CO}_{2}\right]$ on crop growth and their interaction (for Mv Dandár in 2019) were clearly indicated by the higher $C_{R}{ }^{*}$ values, confirmed by increased LAI, SDM and GY. Rising $\left[\mathrm{CO}_{2}\right]$ stimulates photosynthesis and inhibits photorespiration in $\mathrm{C}_{3}$ plants, and also improves water use efficiency (WUE) by reducing stomatal conductance (Wang et al. 2013; Dubey et al. 2015; Manderscheid et al. 2018). These physiological responses often lead to higher above- and belowground productivity, plant height, LAl and GY, usually to a greater extent under adequate $\mathrm{N}$ supply and drought conditions (Amthor 2001, Cai et al. 2016). Increased leaf area and reduced transpirational cooling, however, may counterbalance the improved WUE, increasing the total transpiration and in turn root uptake activity (Manderscheid et al. 2018). Wheat root growth may be stimulated even more than shoot growth by rising $\left[\mathrm{CO}_{2}\right]$, resulting in a higher root/shoot ratio (Benlloch-Gonzalez et al. 2014).

The capacitance technique offered an opportunity to evaluate the treatment effects dynamically. When applying the root core method in a FACE system, Wechsung et al. (1999) revealed that the response of wheat root growth to elevated $\left[\mathrm{CO}_{2}\right]$ was initiated at the 3-leaf stage, and was the largest at stem elongation. These findings agree with the present non-intrusive $C_{R}{ }^{*}$ monitoring and the concurrent crop LAl data. It is worth noting that although $\mathrm{C}_{\mathrm{R}}{ }^{*}$ was closely related to LAl for each cultivar and year (90$96 \%$ explained variance), this could be at least partially explained by the wide range of phenology stages involved in data evaluation, and indicated the strong allometry between root and shoot traits in wheat (Bektas et al. 2016). Furthermore, ceptometer-based LAl may be somewhat overestimated at very large LAl values (Casa et al. 2019), such as those observed in 2019, perhaps contributing to an enhanced difference in regressions between years.

\section{Relationship between electrical capacitance and yield}


The significant relationships observed between $C_{R}$ * (at anthesis) and TAB or GM (65-73\% explained variance) demonstrated the predictive power of capacitance for the aboveground biomass production and yield at a plant scale. Chloupek et al. (2006) found a significant correlation between $C_{R}$ directly measured and shoot biomass ( $\left.R^{2}: 0.42\right)$ for barley. The correlations previously shown between the capacitance-based RSS and GM values of field-grown cereals were significant in dry environments $\left(R^{2}\right.$ : $0.21-0.63)$, but not under optimal water conditions $\left(R^{2}: 0.11-0.14\right)$ in many cases (Chloupek et al. 2010; Středa et al. 2012; Svačina et al. 2014; Heřmanská et al. 2015). In the present study, a significant relationship was also obtained between $C_{R}{ }^{*}$ and $G Y$ at a stand scale using two years' data $\left(R^{2}: 0.805\right.$ and $0.867)$. A weaker correlation $\left(R^{2}: 0.61\right)$ was established previously between directly measured $C_{R}$ and $G Y$ for barley across four varieties and over four years (Chloupek et al. 2010). In the present case, the higher $R^{2}$ values implied that the incorporation of SWC into the measured capacitance improved the predictive accuracy of the method.

Several former studies reported that GY was positively related to wheat RSS traits and the water uptake rate measured at flowering, but these findings were based on the use of destructive techniques (MuñozRomero et al. 2010; Man et al. 2016) and minirhizotrons (Postic et al. 2019), or were performed in rhizoboxes (Fang et al. 2017). Although Mv Nemere and Mv Dandár presented statistically similar regressions, this is always so when cultivars possessing different phenotypic characteristics and root architecture are compared (Středa et al. 2020; Cseresnyés et al. 2021).

\section{Overall evaluation}

In a given year, the responses of wheat to the $\mathrm{N}$ and $\mathrm{CO}_{2}$ treatments were clearly indicated by $\mathrm{C}_{\mathrm{R}}{ }^{*}$, in accordance with changes in biomass and yield. Comparing the two years, however, the maximum $\mathrm{C}_{\mathrm{R}}{ }^{*}$ values were equivalent, and GY decreased only slightly for Mv Dandár despite the substantially reduced maximum LAI and SDM for both cultivars in 2021. These findings were supported by the different $\mathrm{C}_{\mathrm{R}}{ }^{*}$ LAl relationships between years, as well as by the insignificant and significant $C_{R}{ }^{*}-S D M$ and $C_{R}{ }^{*}-G Y$ correlations, respectively, established for the two-year data. As destructive root quantification was unfeasible in the present FACE study to further validate the $C_{R}{ }^{*}$ data, this result is hypothesized to be due to an enhanced root/shoot ratio in response to the severe spring drought in 2021 . The increased biomass allocation to the roots was later able to compensate for the yield loss under the more favourable growing conditions that prevailed around flowering. Furthermore, $C_{R}{ }^{*}$ was unaffected by the reduction in SDM, implying that the capacitance is more or less determined by the root traits and not merely by the root-neck and stem-base properties. This corroborates previous findings by Gu et al. (2021), who reported poorer correlations between stem diameter and $C_{R}$ under relatively dry soil conditions when the current used for measurement penetrated deep into the root system. In a pot experiment, Wu et al. (2016) also observed a stronger relationship between $\mathrm{C}_{\mathrm{R}}$ and RSS traits before than after surface irrigation. It should be noted that though $C_{R}{ }^{*}$ values were calculated for water-saturated soil, the capacitance measurements in the present study were taken under much drier conditions $\left(\theta_{\text {rel }}\right.$ from 0.2 to 0.5$)$ in most cases. 


\section{Conclusions}

The present study convincingly demonstrated the potential of measuring $\mathrm{C}_{\mathrm{R}}{ }^{*}$ to reveal the seasonal pattern of root development and uptake activity, and to assess the response of root and shoot growth and seed production to various treatments in the field. The non-destructive character of the method enables it to evaluate environmental effects over time using the same plant population (or even the same individual plants) for repeated measurements. Moreover, the approach proved to be useful for the early estimation of changes in GY across years. Nevertheless, more research is required to strengthen the link between $C_{R}{ }^{*}$ measured at flowering and GY at a stand scale over many years, and to further validate the capacitance results via the concurrent investigation of changes in root biomass and root/shoot ratio (even destructively outside the FACE area).

While it is true that neither the underlying biophysical principles nor the current pathways between the electrodes are as yet fully understood, the capacitance method should be considered to be a rapid, inexpensive approach for the dynamic evaluation of root responses to environmental changes without damaging the plant or disturbing the soil. As $C_{R}{ }^{*}$ represents a functional root size, it may provide an adequate prediction of GY. One current challenge facing breeding programs is the selection of crop genotypes having higher physiological plasticity and responsiveness to changing climatic events, such as rising $\left[\mathrm{CO}_{2}\right]$, extreme temperatures and drought. Capacitance measurement, as a simple, in situ, highthroughput root phenotyping tool could partially replace invasive routine field techniques, and may thus be of interest for future application.

\section{Abbreviations}

$A C$ - alternating current; $C_{R}$ - root electrical capacitance; $C_{R}{ }^{*}$ - saturation root electrical capacitance; FACE - free-air $\mathrm{CO}_{2}$ enrichment; $\mathrm{GM}$ - grain mass; $\mathrm{GY}$ - grain yield; LAI - leaf area index; RSS - root system size; SDM - shoot dry mass; SWC - soil water content; TAB - total aboveground biomass; $\theta_{\text {rel }}$ Relative water saturation

\section{Declarations}

\section{Acknowledgments}

The project was funded by the National Research, Development and Innovation Fund of Hungary (Project No. 137617, financed under the FK-21 funding scheme), by the Hungarian Government (GINOP-2.3.2-152016-00028) and by grant "Advanced research supporting the forestry and wood-processing sector's adaptation to global change and the $4^{\text {th }}$ industrial revolution" (CZ.02.1.01/0.0/0.0/16_019/0000803) financed by OP RDE". The authors thank Prof. Kálmán Rajkai for valuable remarks and Barbara Harasztos for language editing.

Conflict of interest: The authors declare that they have no conflict of interest. 


\section{References}

1. Amthor JS (2001) Effects of atmospheric $\mathrm{CO}_{2}$ concentration on wheat yield: review of results from experiments using various approaches to control $\mathrm{CO}_{2}$ concentration. Field Crops Res 73:1-34. doi:10.1016/S0378-4290(01)00179-4

2. Asseng S, Ritchie JT, Smucker AJM, Robertson MJ (1998) Root growth and water uptake during water deficit and recovering in wheat. Plant Soil 201:265-273. doi:10.1023/A:1004317523264

3. Bektas H, Hohn, CE, Waines JG (2016) Root and shoot traits of bread wheat (Triticum aestivum L.) landraces and cultivars. Euphytica 212:297-311. doi:10.1007/s10681-016-1770-7

4. Benlloch-Gonzalez M, Berger J, Bramley H, Rebetzke G, Palta JA (2014) The plasticity of the growth and proliferation of wheat root system under elevated $\mathrm{CO}_{2}$. Plant Soil 374:963-976. doi:10.1007/s.11104-013-1934-3

5. Broberg MC, Högy P, Feng Z, Pleijel H (2019) Effects of elevated $\mathrm{CO}_{2}$ on wheat yield: non-linear response and relation to site productivity. Agronomy 9:243. doi:10.3390/agronomy 9050243

6. Cabal C, Deurwaerder HPT de, Matesanz S (2021) Field methods to study the spatial root density distribution of individual plants. Plant Soil 462: 25-43. doi: 10.1007/s11104-021-04841-z

7. Casa R, Upreti D, Pelosi F (2019) Measurement and estimation of leaf area index (LAl) using commercial instruments and smartphone-based systems. IOP Conference Series: Earth and Environmental Sciences 275:012006. doi:10.1088/1755-1315/275/1/012006

8. Cai C, Yin X, He S, Jiang W, Si C, Struik PC, Luo W, Li G, Xie Y, Xiong Y, Pan G (2016) Responses of wheat and rice to factorial combinations of ambient and elevated $\mathrm{CO}_{2}$ and temperature in FACE experiments. Glob Change Biol 22:856-874. doi:10.1111/gcb.13065

9. Carlson CH, Smart LB (2016) Electrical capacitance as a predictor of root dry weight in shrub willow (Salix, Salicaceae) parents and progeny. Appl Plant Sci 4:1600031. doi:10.3732/apps.1600031

10. Chloupek O, Forster BP, Thomas WTB (2006) The effect of semi-dwarf genes on root system size in field-grown barley. Theor Appl Genet 112:779-786. doi:10.1007/s00122-005-0147-4

11. Chloupek O, Dostál V, Středa T, Psota V, Dvořáčková O (2010) Drought tolerance of barley varieties in relation to their root system size. Plant Breeding 129:630-636. doi:10.1111/j.14390523.2010.01801.x

12. Cseresnyés I, Szitár K, Rajkai K, Füzy A, Mikó P, Kovács R, Takács T (2018) Application of electrical capacitance method for prediction of plant root mass and activity in field-grown crops. Front Plant Sci 9:93. doi:10.3389/fpls.2018.00093

13. Cseresnyés I, Vozáry E, Kabos S, Rajkai K (2020a) Influence of substrate type and properties on root electrical capacitance. Int Agrophys 34:95-101. doi:10.31545/intagr/112147

14. Cseresnyés I, Vozáry E, Rajkai K (2020b) Does electrical capacitance represent roots in the soil? Acta Physiol Plant 42: 71. doi:10.1007/s11738-020-03061-9 
15. Cseresnyés I, Mikó P, Kelemen B, Füzy A, Parádi I, Takács T (2021) Prediction of wheat grain yield by measuring root electrical capacitance at anthesis. Int Agrophys 35:159-165. doi:10.31545/intagr/136711

16. Dalton FN (1995) In-situ root extent measurements by electrical capacitance methods. Plant Soil 173:157-165. doi:10.1007/BF00155527

17. Dietrich RC, Bengough AG, Jones HG, White PJ (2012) A new physical interpretation of plant root capacitance. J Exp Bot 63:6149-6159. doi:10.1093/jxb/ers264

18. Dubey SK, Tripatri SK, Pranuthi G (2015) Effect of elevated $\mathrm{CO}_{2}$ on wheat crop: mechanism and impact. Crit Rev Env Sci Tech 45:2283-2304. doi:10.1080/10643389.2014.1000749

19. Ehosioke S, Nguyen F, Rao S, Kremer T, Placencia-Gomez E, Huisman JA, Kemna A, Javaux M, Garré $S$ (2020) Sensing the electrical properties of roots: A review. Vadose Zone J 19:e20082. doi:10.1002/vzj2.20082

20. Ellis T, Murray W, Paul K, Kavalieris L, Brophy J, Williams C, Maass M (2013) Electrical capacitance as a rapid and non-invasive indicator of root length. Tree Physiol 33:3-17. doi:10.1093/treephys/tps115

21. Fageria NK (2013) The Role of Plant Roots in Crop Production. CRC Press, Boca Raton, FL.

22. Fang Y, Du Y, Wang J, Wu A, Qiao S, Xu B, Zhang S, Siddique KHM, Chen Y (2017) Moderate drought stress affected root growth and grain yield in old, modern and newly released cultivars of winter wheat. Front Plant Sci 8:672. doi:10.3389/fpls.2017.00672

23. Gu H, Liu L, Butnor JR, Sun H, Zhang X, Li C, Liu X (2021) Electrical capacitance estimates crop root traits best under dry conditions - a case study in cotton (Gossypium hirsutum L.). Plant Soil 467:549-567. doi:10.1007/s11104-021-05094-6

24. Heřmanská A, Středa T, Chloupek O (2015) Improved wheat grain yield by a new method of root selection. Agron Sustain Develop 35:195-202. doi:10.1007/s13593-014-0227-4

25. IUSS Working Group (2015) World Reference Base (WRB) for Soil Resources. International soil classification system for naming soils and creating legends for soil maps. World Soil Resources Reports 106, FAO, Rome.

26. Jha SK, Gao Y, Liu H, Huang Z, Wang G, Liang Y, Duan A. (2017) Root development and water uptake in winter wheat under different irrigation methods and scheduling for North China. Agr Water Manage 182:139-150. doi:10.1016/j.agwat.2016.12.015

27. Kirkham MB (2011) Elevated carbon dioxide. Impacts on soil and plant water relations. CRC Press, Boca Raton, FL.

28. Man J, Shi Y, Yu Z, Zhang Y (2016) Root growth, soil water variation, and grain yield response of winter wheat to supplemental irrigation. Plant Prod Sci 19:193-205.

doi:10.1080/1343943X.2015.1128097

29. Manderscheid R, Dier M, Erbs M, Sickora J, Weigel H-J (2018) Nitrogen supply - A determinant in water use efficiency of winter wheat grown under free air $\mathrm{CO}_{2}$ enrichment. Agr Water Manage 
210:70-77. doi:10.1016/j.agwat.2018.07.034

30. Mary B, Peruzzo L, Boaga J, Schmutz M, Wu Y, Hubbard SS, Cassiani G (2018) Small-scale characterization of vine plant root water uptake via 3-D electrical resistivity tomography and mise-àla-masse method. Hydrol Earth Syst Sci 22:5427-5444. doi:10.5194/hess-22-5427-2018

31. Meier U (2001; ed): Growth stages of mono- and dicotyledonous plants. BBCH Monograph. $2^{\text {nd }}$ Ed. Federal Biological Research Centre for Agriculture and Forestry, Berlin.

32. Miglietta F, Peressotti, A, Vaccari FP, Zaldei A, deAngelis P, Scarascia-Mugnozza G (2001) Free-air $\mathrm{CO}_{2}$ enrichment (FACE) of a poplar plantation: the POPFACE fumigation system. New Phytol 150:465476. doi:10.1046/j.1469-8137.2001.00115.x

33. Muñoz-Romero V, Benítez-Vega J, López-Bellido L, López-Bellido RJ (2010) Monitoring wheat root development in a rainfed vertisol: Tillage effect. Eur J Agron 33:182-187. doi:10.1016/j.eja.2010.05.004

34. Ozier-Lafontaine $\mathrm{H}$, Bajazet T (2005) Analysis of root growth by impedance spectroscopy (EIS). Plant Soil 277:299-313. doi:10.1007/s11104-005-7531-3

35. Peruzzo L, Chou C, Wu Y, Schmutz M, Mary B, Wagner FM, Petrov P, Newman G, Blancaflor EB, Liu X, Ma X, Hubbard S (2020) Imaging of plant current pathways for non-invasive root phenotyping using a newly developed electrical current source density approach. Plant Soil 450:567-584. doi:10.1007/s11104-020-04529-w

36. Pokovai K, Fodor N (2019) Adjusting ceptometer data to improve leaf area index measurements. Agronomy 9:866. doi:10.3390/agronomy9120866

37. Postic F, Beauchêne K, Gouache D, Doussan C (2019) Scanner-based minirhizotrons help to highlight relations between deep roots and yield in various wheat cultivars under combined water and nitrogen deficit conditions. Agronomy 9:297. doi:10.3390/agronomy9060297

38. R Core Team (2021) A language and environment for statistical computing. Vienna, Austria: R Foundation for Statistical computing. http://www.R-project.org/

39. Středa T, Dostál V, Horáková V, Chloupek O (2012) Effective use of water by wheat varieties with different root system sizes in rain-fed experiments in Central Europe. Agr Water Manage 104:203209. doi:10.1016/j.agwat.2011.12.018

40. Středa T, Haberle J, Klimešová J, Klimek-Kopyra A, Středová H, Bodner G, Chloupek O (2020) Field phenotyping of plant roots by electrical capacitance - a standardized methodological protocol for application in plant breeding: a review. Int Agrophys 34:173-184. doi:10.31545/intagr/117622

41. Svačina P, Středa T, Chloupek O (2014) Uncommon selection by root system size increases barley yield. Agron Sustain Develop 34:545-551. doi:10.1007/s13593-013-0160-y

42. Uddin S, Löw M, Parvin S, Fitzgerald G, Bahrami H, Tausz-Posch S, Armstrong R, O'Leary G, Tausz M (2018) Water use and growth response of dryland wheat grown under elevated $\left[\mathrm{CO}_{2}\right]$ are associated with root length in deeper, but not upper soil layer. Field Crops Res 224:170-181.

doi:10.1016/j.fcr.2018.05.014

Page $17 / 24$ 
43. Urban J, Bequet R, Mainiero R (2011) Assessing the applicability of the earth impedance method for in situ studies of tree root systems. J Exp Bot 62:1857-1869. doi:10.1093/jxb/erq370

44. Wang L, Feng Z, Schjoerring JK (2013) Effects of elevated atmospheric $\mathrm{CO}_{2}$ on physiology and yield of wheat (Triticum aestivum L.): A meta-analytic test of current hypotheses. Agr Ecosyst Environ 178:57-63. doi:10.1016/j.agee.2013.06.013

45. Wechsung G, Wechsung F, Wall GW, Adamsen FJ, Kimball BA, Pinter PJ, Lamorte RL, Garcia RL, Kartschall T (1999) The effects of free-air $\mathrm{CO}_{2}$ enrichment and soil water availability on spatial and seasonal patterns of wheat root growth. Glob Change Biol 5:519-529. doi:10.1046/j.13652486.1999.00243.x

46. Wu W, Ma B-L (2016) A new method for assessing plant lodging and the impact of management options on lodging in canola crop production. Sci Reports 9:31890. doi:10.1038/srep31890

47. Xue Q, Zhu Z, Musick JT, Stewart BA, Dusek DA (2003) Root growth and water uptake in winter wheat under deficit irrigation. Plant Soil 257:151-161. doi:10.1023/A:1026230527597

48. Yang B, Wang P, You D, Liu W (2018) Coupling evapotranspiration partitioning with root water uptake to identify the water consumption characteristics of winter wheat: A case study in the North China Plain. Agr Forest Meteorol 259:296-304. doi:10.1016/j.agrformet.2018.05.017

\section{Figures}

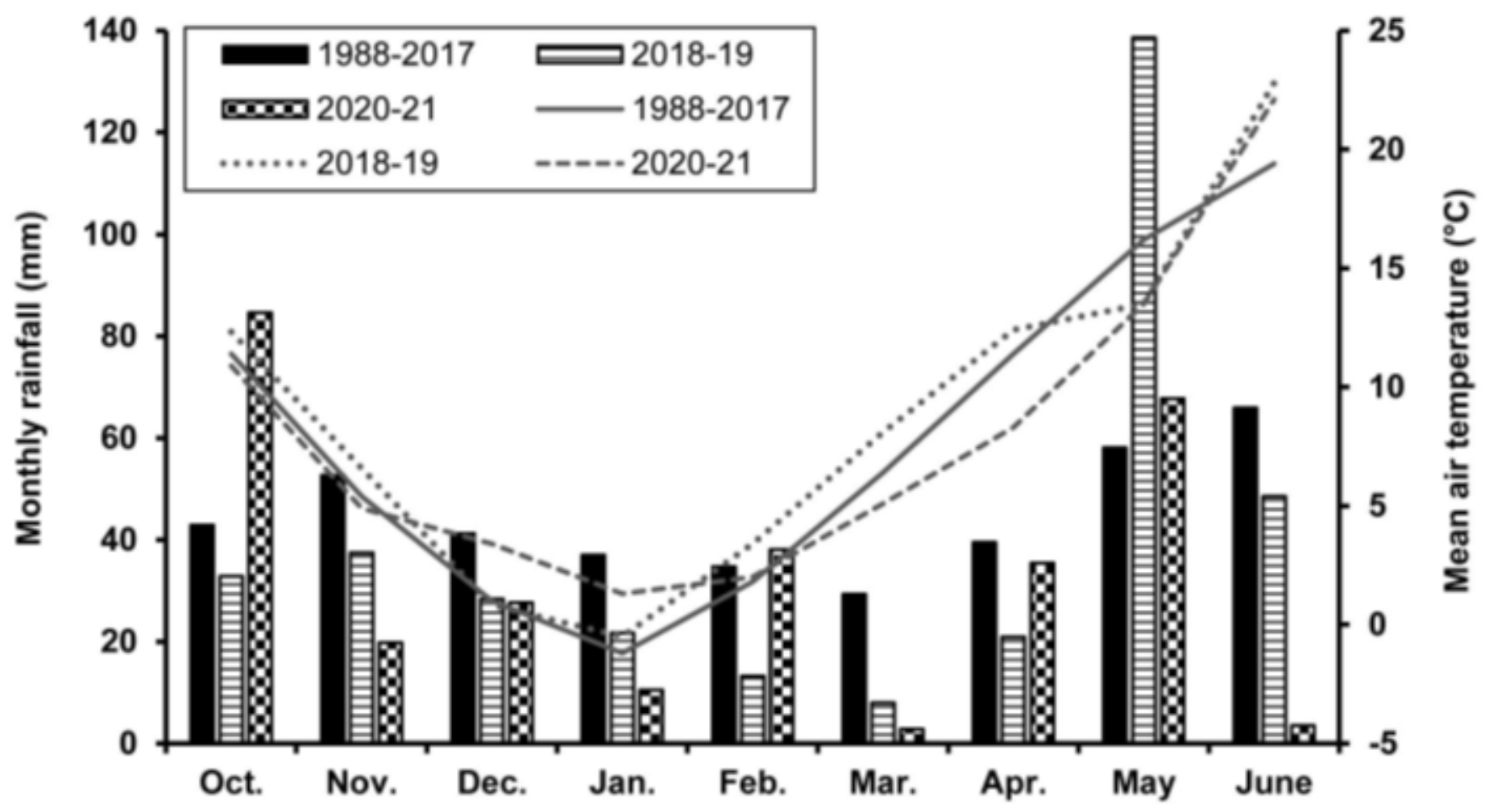

Figure 1 
Monthly rainfall (mm; columns) and mean air temperature $\left({ }^{\circ} \mathrm{C}\right.$; lines) in the nursery of the Centre for Agricultural Research (Martonvásár, Hungary) during the winter wheat growing seasons. Long-term (1988-2017) average is displayed for reference.
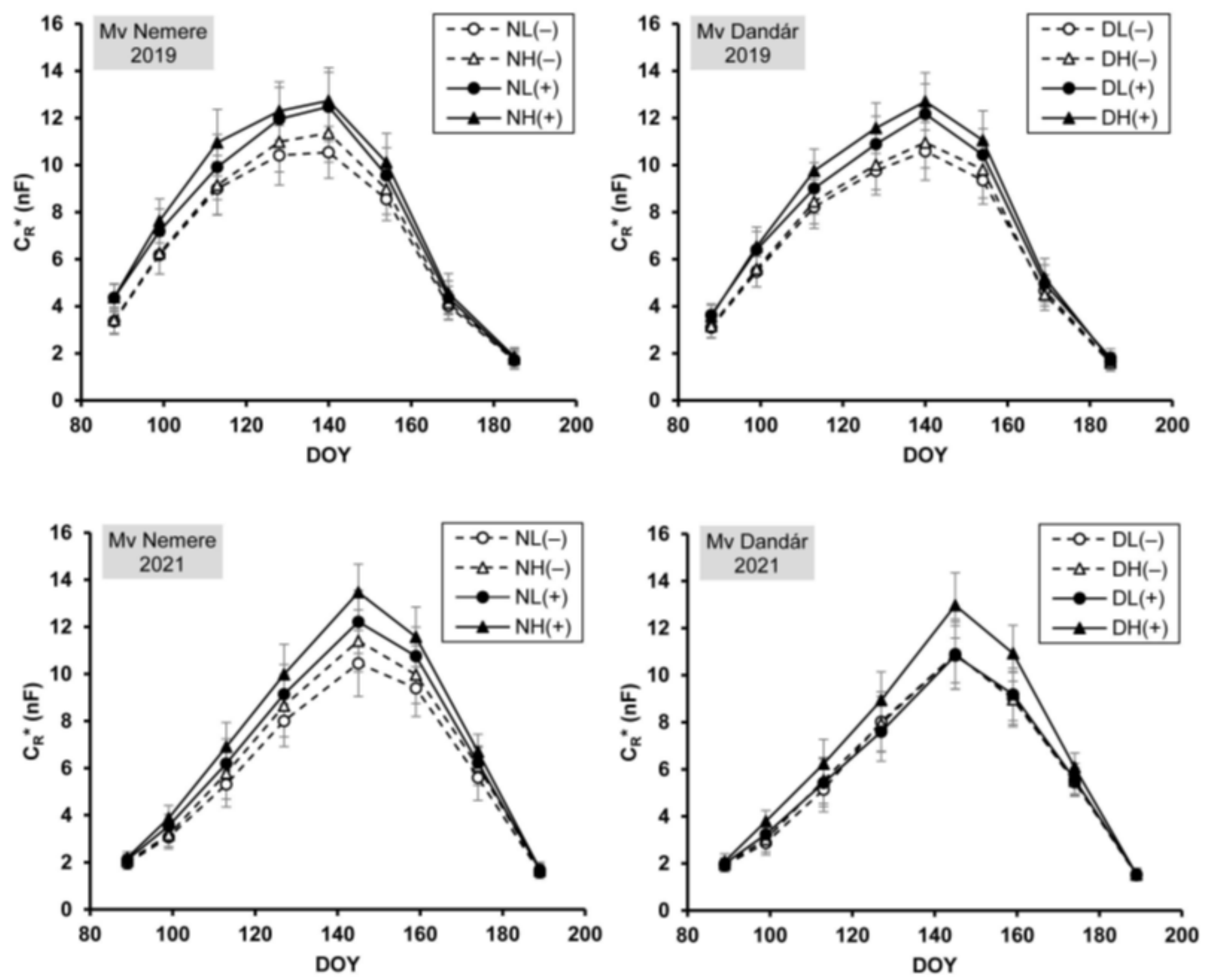

Figure 2

Changes in the saturation root electrical capacitance $\left(\mathrm{C}_{\mathrm{R}}\right.$ * in nanofarads, $\left.\mathrm{nF}\right)$ over time (DOY - day of year) for wheat cultivars Mv Nemere ("N") and Mv Dandár ("D") grown under low ("L") or high (" $\left.\mathrm{H}^{\prime \prime}\right) \mathrm{N}$ supply under ambient $("-")$ or elevated $("+")\left[\mathrm{CO}_{2}\right]$ in two years. Vertical bars represent SDs $(n=36)$. 

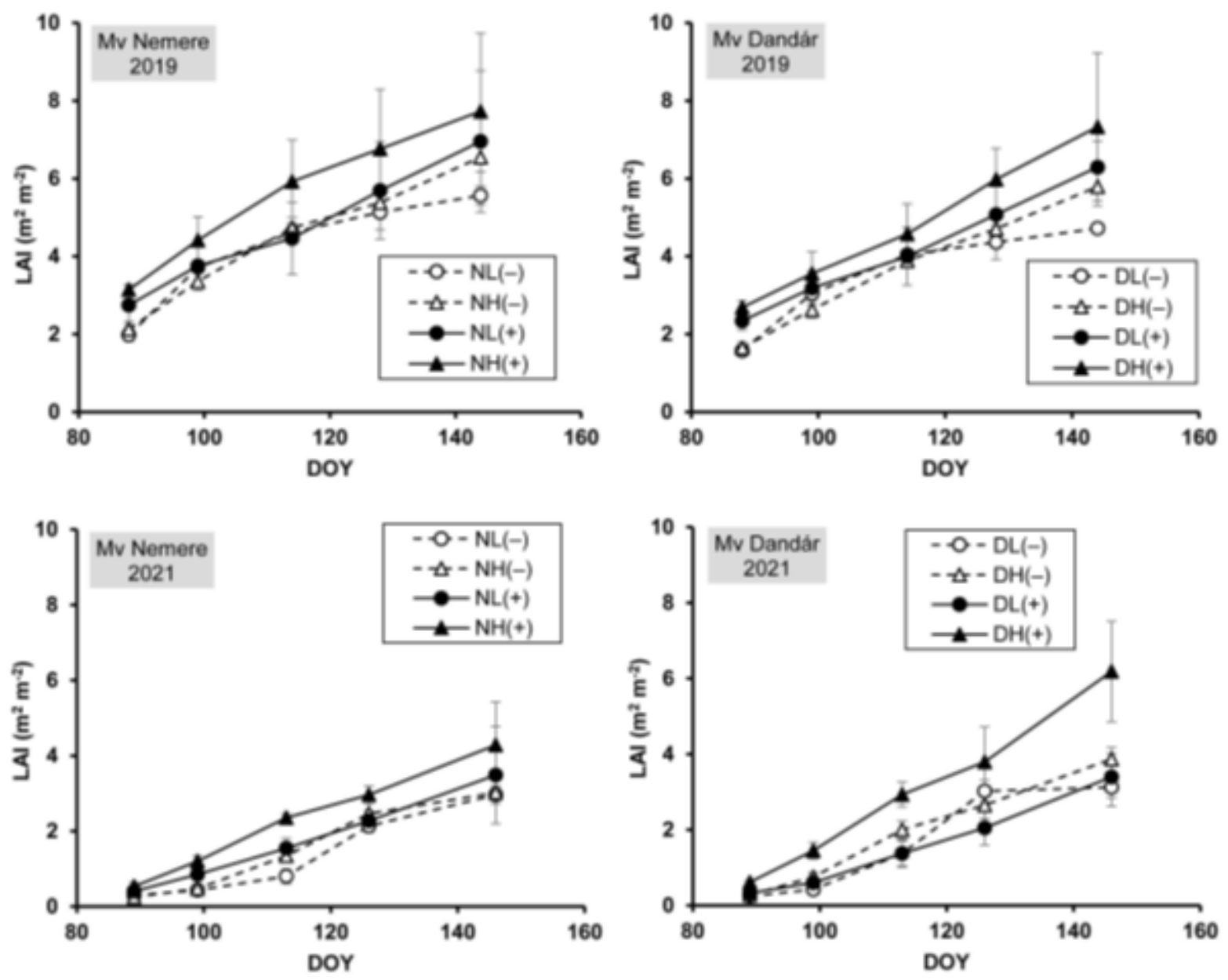

Figure 3

Changes in the leaf area index (LAl) over time (DOY - day of year) for wheat cultivars Mv Nemere ("N") and Mv Dandár ("D") grown under low ("L") or high ("H") N supply under ambient ("- ") or elevated ("+") $\left[\mathrm{CO}_{2}\right]$ in two years. Vertical bars represent SDs $(n=3)$. 


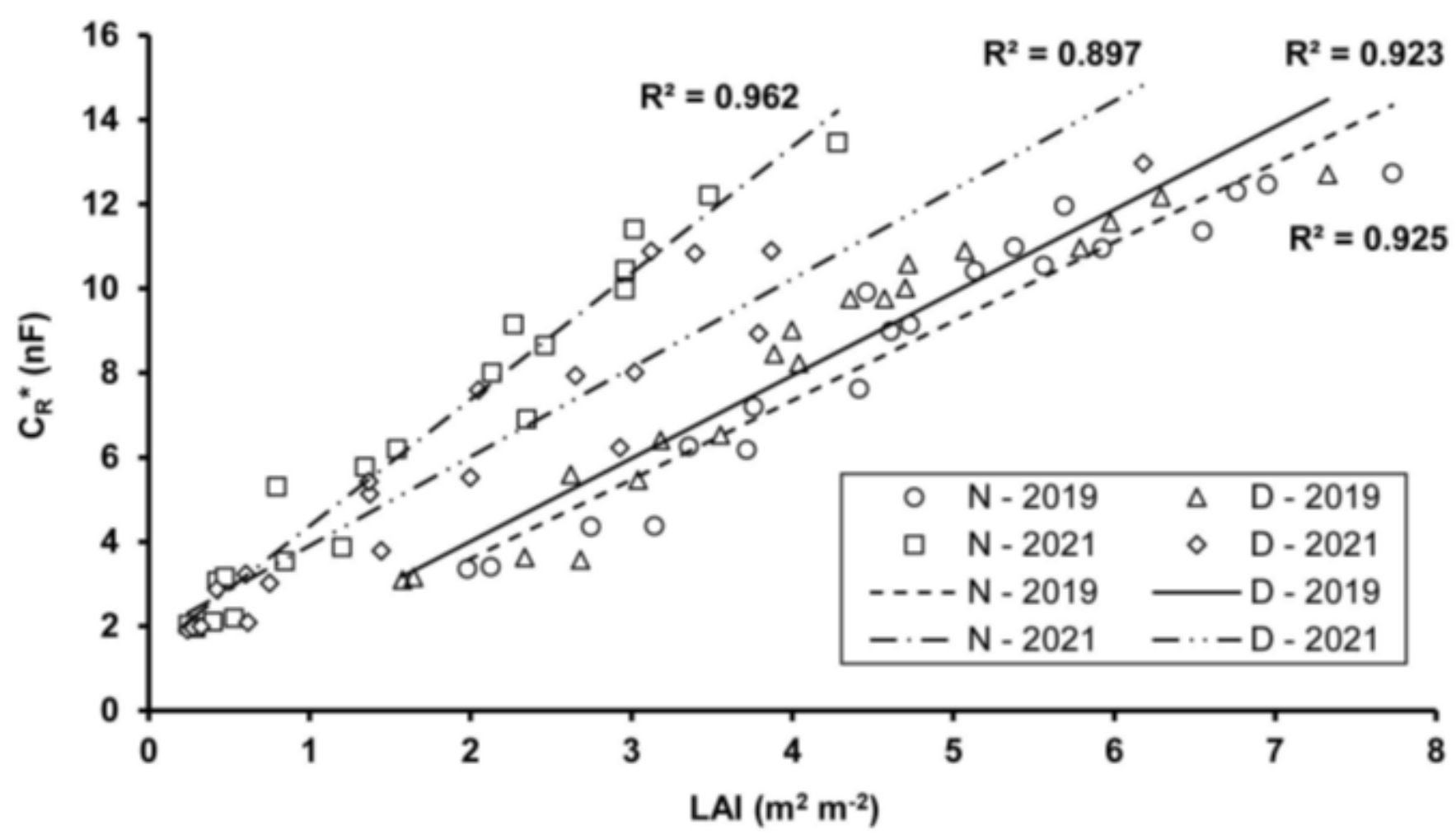

Figure 4

Relationships between the saturation root electrical capacitance $\left(\mathrm{C}_{R}{ }^{\star}\right)$ and leaf area index (LAl) for wheat cultivars Mv Nemere ("N") and Mv Dandár ("D") in two years. For each cultivar, data were pooled across $\mathrm{N}$ and $\mathrm{CO}_{2}$ treatments $(\mathrm{n}=20)$. Regressions were significant at the $p<0.001$ level. 

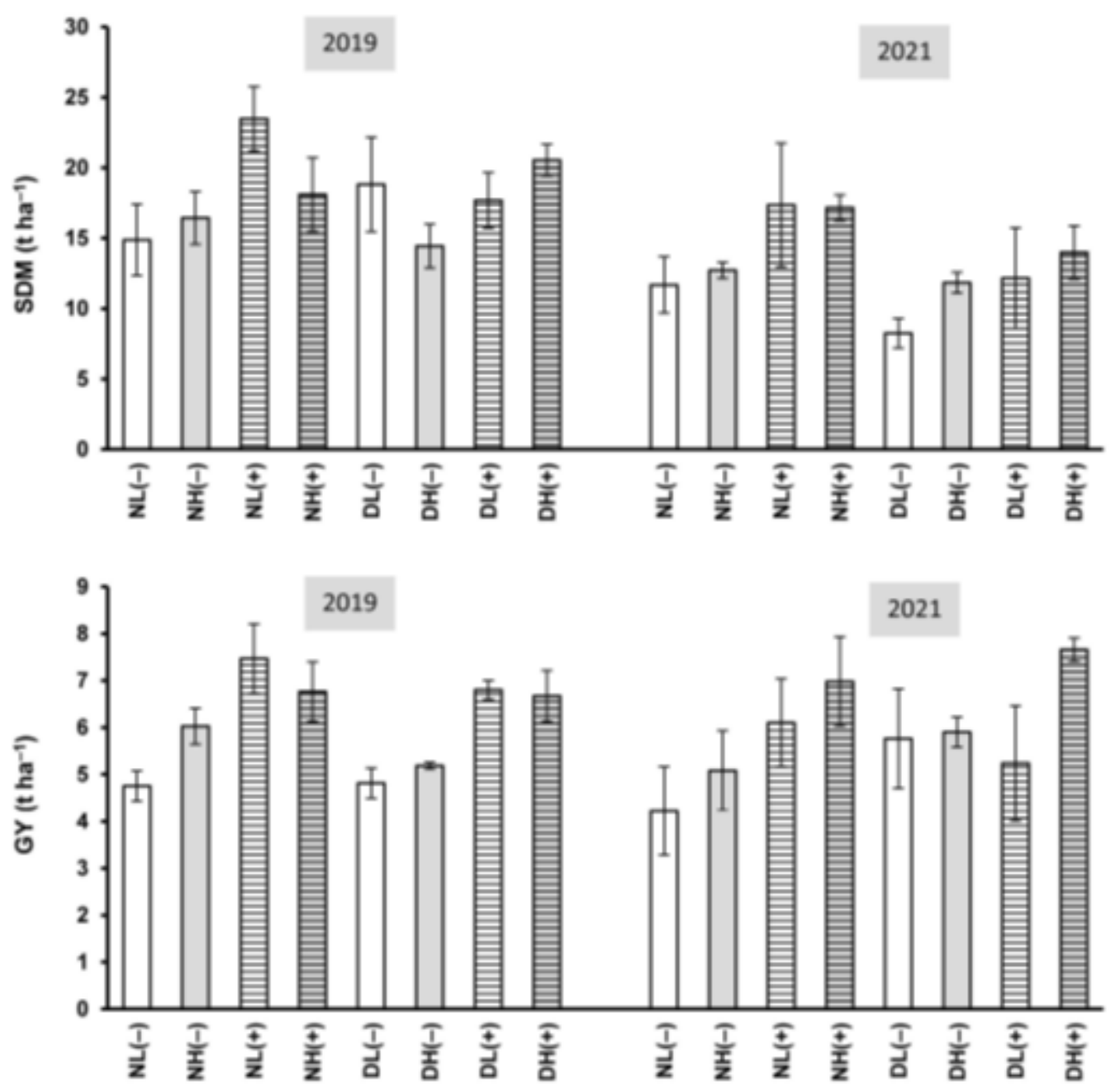

Figure 5

Shoot dry mass (SDM) and grain yield (GY) of wheat cultivars Mv Nemere ("N") and Mv Dandár ("D") grown under low ("L") or high ("H") N supply under ambient ("- ") or elevated ("+ + ") $\left[\mathrm{CO}_{2}\right]$ in two years. Vertical bars represent SDs $(n=3)$. 

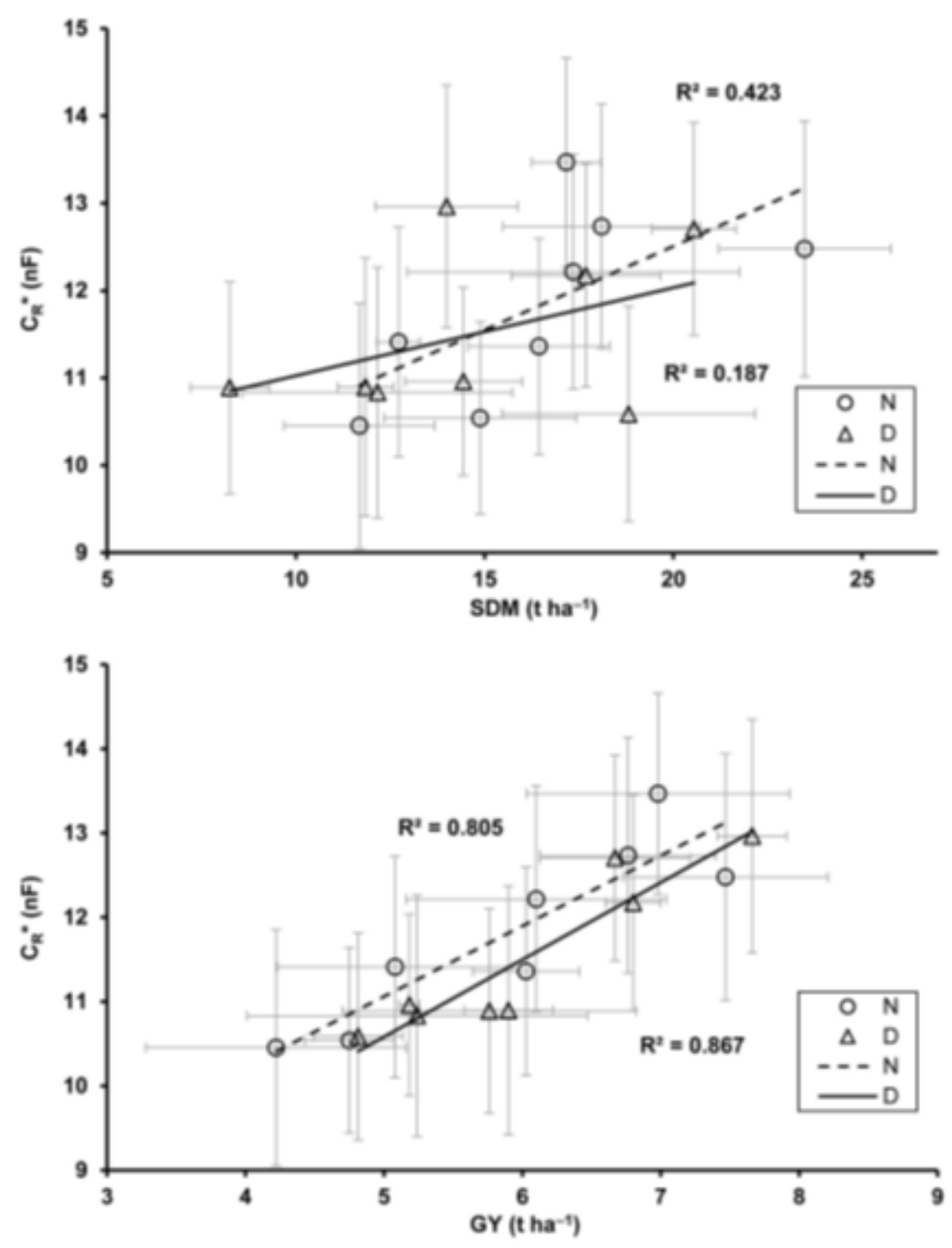

\section{Figure 6}

Relationships between the maximum saturation root electrical capacitance $\left(C_{R}{ }^{*}\right)$ and shoot dry mass (SDM) and grain yield (GY) for wheat cultivars Mv Nemere ("N") and Mv Dandár ("D"). For each cultivar, data were pooled across $\mathrm{N}$ and $\mathrm{CO}_{2}$ treatments and years $(n=8)$. Horizontal and vertical bars represent SDs. The $C_{R}{ }^{*}-S D M$ regressions were insignificant, the $C_{R}{ }^{*}-G Y$ regressions were significant at the $p<$ 0.01 level. 

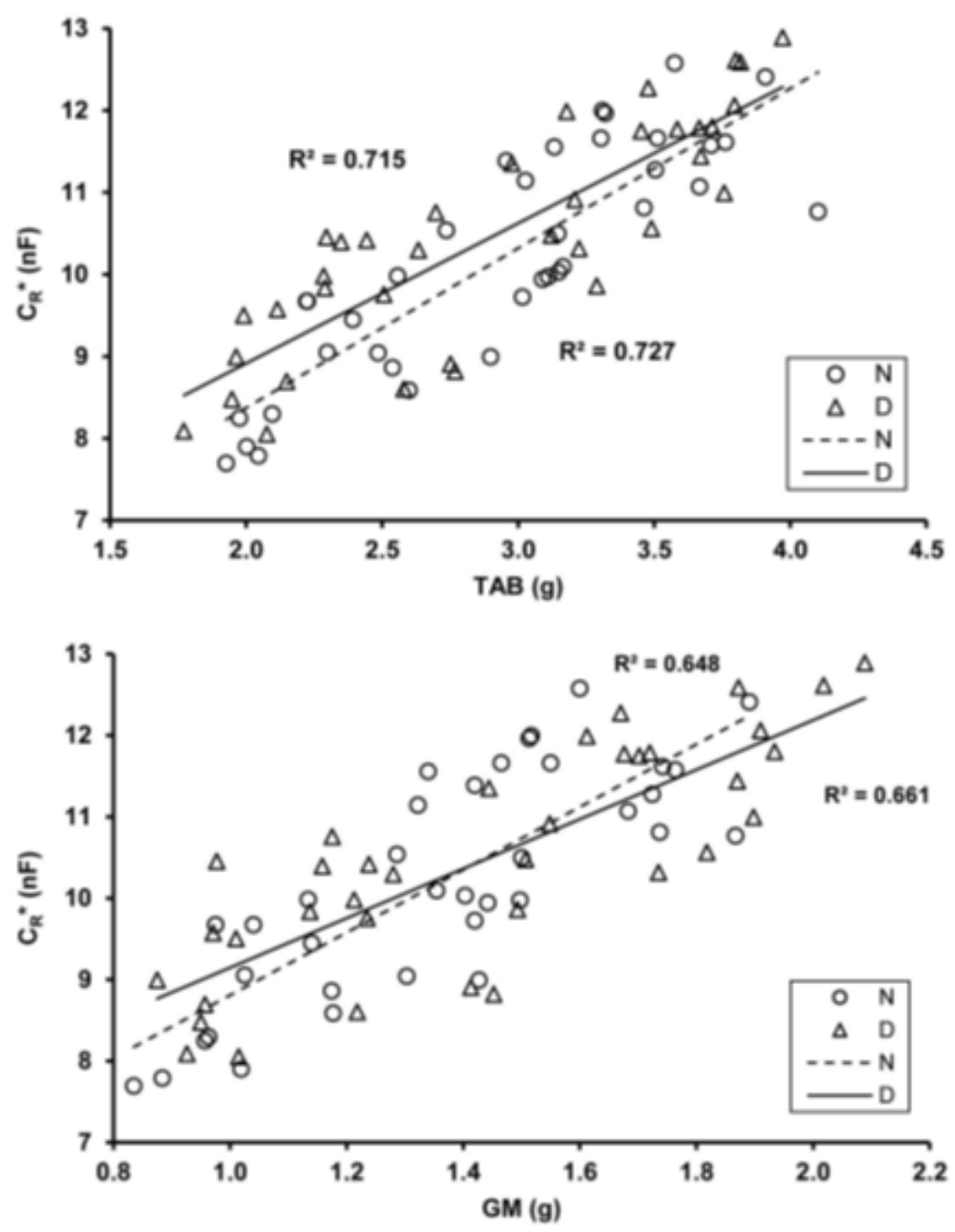

Figure 7

Relationships between the saturation root electrical capacitance $\left(C_{R}{ }^{*}\right)$ measured at the flowering stage and the total aboveground biomass (TAB) and grain mass (GM) per plant for wheat cultivars Mv Nemere $(" N$ ") and Mv Dandár ("D"). Regressions were significant at the $p<0.001$ level $(n=36)$. 